\title{
MEMBANGUN KARAKTER BANGSA MELALUI \\ PENDIDIKAN MULTIKULTUR
}

\author{
Oleh \\ Ni Wayan Budiasih
}

\begin{abstract}
ABSTRAK
Wawasan kebangsaan mengandung tuntutan suatu bangsa untuk mewujudkan jati diri, serta mengembangkan karakter dan perilaku sebagai bangsa yang meyakini nilai-nilai budayanya yang lahir dan tumbuh sebagai penjelmaan kepribadiannya. Bila nilai-nilai kebangsaan tidak terus menerus ditanamkan dan mengingat kondisi sosial politik ekonomi Indonesia yang sangat beragam, maka keragaman budaya tersebut berpotensi menjadi modal perpecahan dan konflik. Oleh karena itu, pendidikan multikultural sangat menekankan pentingnya akomodasi hak setiap kebudayaan dan masyarakat sub-nasional (etnis) untuk memelihara dan mempertahankan identitas kebudayaan dan masyarakat nasional. Sehingga Bangsa nantinya memiliki karakter yang baik dan bangsa yang terhormat serta dapat menjadi teladan bangsa-bangsa lain di dunia.
\end{abstract}

Kata kunci: karakter, pendidikan multikultur, bangsa

\section{ABSTRACT}

Insights on nationality contain the demands of a nation to realize one's identity, and develop character and behavior as a nation that believes in its cultural values that are born and grow as the incarnation of its personality. If national values are not continuously implanted and given Indonesia's diverse socio-economic economic conditions, the cultural diversity has the potential to become a capital of division and conflict. Therefore, multicultural education strongly emphasizes the importance of the accommodation of the rights of every sub-national (ethnic) culture and society to maintain and maintain national cultural identity and society. So that the Nation will have good character and a respectable nation and can be a role model for other nations in the world.

Keywords: character, multicultural education, nation

\section{PENDAHULUAN}

Pendidikan karakter mempunyai fungsi strategis bagi kemajuan bangsa, harus ada komitmen untuk menjalankan pendidikan karakter sebagai bagian dari jati diri bangsa. Komitmen yang harus kita jalankan semua, mengacu kepada 5 nilai karakter bangsa untuk menjadi manusia unggul yaitu:

1. Manusia Indonesia yang bermoral, berakhlak dan berperilaku baik;

2. Mencapai masyarakat yang cerdas dan rasional;
3. Manusia Indonesia ke depan menjadi manusia yang inovatif dan terus mengejar kemajuan;

4. Memperkuat semangat "Harus Bisa", yang terus mencari solusi dalam setiap kesulitan;

5. Manusia Indonesia haruslah menjadi patriot sejati yang mencintai bangsa, Negara dan tanah airnya.

Pendidikan bukan hanya membangun kecerdasan dan transfer of knowledge, tetapi juga harus mampu membangun karakter atau 
character building dan perilaku. Dengan hakekat pendidikan dan dibangun metodologi yang tepat, maka diharapkan dapat dibangun intellectual curiosity dan membangun common sense. Tidak bisa ditunda lagi, generasi penerus bangsa harus serius untuk dibekali pendidikan karakter agar dapat memenuhi 5 nilai manusia unggul di atas (Dewangga, 2012).

Secara historis dapat diketahui bahwa rasa nasionalisme dapat membangkitkan bangsa Indonesia terbebas dari cengekraman penjajah. Untuk konteks masa kini, nasionalisme inilah yang dapat membangkitkan bangsa Indonesia yang masih sangat besar dependensi (ketergantungan)-nya pada bangsa-bangsa lain, agar menjadi bangsa yang benar-benar memiliki independensi (kemandirian) dan selanjutnya mencapai interdependensi, memiliki keunggulan dalam berbagai bidang untuk dapat bekerja secara sinergis baik dengan suku-suku bangsa (etnis) yang ada di Indonesia maupun dengan bangsa lain. Sayangnya nasionalisme tersebut mulai menipis. Menurut Thomas Lickona (1992), ada sepuluh tanda dari perilaku manusia yang menunjukkan arah kehancuran suatu bangsa, yaitu:

1. Meningkatnya kekerasan di kalangan remaja.

2. Ketidakjujuran yang membudaya.

3. Semakin tingginya rasa tidak hormat kepada orangtua, guru dan pemimpin.

4. Pengaruh peergroup terhadap tindak kekerasan.

5. Meningkatnya kecurigaan dan kebencian.

6. Penggunaan bahasa yang memburuk.

7. Penurunan etos kerja

8. Menurunnya rasa tanggung jawab sosial individu dan warga negara.

9. Meningginya perilaku merusak diri.

10. Semakin hilangnya pedoman moral.

Sepuluh hal inilah yang menunjukkan tanda kehancuran suatu bangsa. Apa yang dikatakan oleh Lickona di atas hampir semua dapat dilihat telah terjadi di Indonesia. Seperti perkelahian pelajar dan mahasiswa (tawuran); cukup banyak orangtua, guru dan para pemimpin yang melakukan tindakan tidak terpuji dan menghilangkan rasa hormat anak pada mereka, atau anak yang tega membunuh orangtua karena kemauannya tidak dituruti. Maraknya kelompok anakanak muda yang melakukan kriminal, contoh geng motor, memperkosa bersama-sama, dan sebagainya. Meningkatnya rasa bermusuhan antaretnis, antaragama. Cara berkomunikasi yang menebarkan rasa bermusuhan, konflik dan saling memojokkan, sangat sering kita dengar di lingkungan atau melalui media. Ajaran para tetua dulu terutama pada budaya Jawa untuk menggunakan bahasa kromo yang santun sudah lama ditinggalkan. Perilaku merusak diri dengan narkoba, minuman keras dan perilaku seks bebas terus saja bertambah jumlahnya. Etos kerja yang rendah dan bermimpi punya uang banyak, membuat penipuan, pencurian, dan korupsi merajalela. Pemberitaan yang riuh dan simpang siur oleh media-media yang komersial membuat warga semakin kehilangan pedoman moral (Hanum, 2011)

\section{PEMBAHASAN}

Karakter menurut naskah rencana aksi nasional yang diterbitkan kementerian pendidikan nasional merupakan merupakan kualitas individu atau kolektif yang menajdi ciri individu atau kelompok. Karakter yang dimaksud di sini bisa berbentuk baik maupun buruk. Karakter yang ingin diwujudkan oleh bangsa Kita merupakan karakter yang baik dan bisa berjalan sejalan dengan tantangan dan perubahan zaman. Aktualisasi dari pembentukan karakter melalui pendidikan memerlukan pengembangan yang terintegrasi antara aspek-aspek perkembangan siswa secara seimbang baik afeksi maupun kognisi. Di sinilah pentingnya pendidikan bagi manusia yang seimbang antara afeksi dan 
kognisi, yakni untuk mewujudkan karakter yang kukuh dan unggul pada diri generasi penerus Upputra, 2016: http://guruppkn. com). Menurut Prof. Dr. Farida Hanum (2011, dalam: http://uun-halimah.blogspot.co.id) Strategi membangun karakter bangsa melalui pendidikan multikultural dapat dilakukan dengan beberapa cara, sebagai berikut.

a. Melatih Anak Sejak Dini Memahami Orang Lain di Sekitarnya

Manusia dengan berbagai ragam karakteristik dan pola pikirnya, bukanlah sebuah petaka, melainkan merupakan potensi. Untuk mengoptimalkan potensi tersebut perlu kesadaran rakyat negeri ini untuk saling mengenal dan memahami orang di sekitarnya. Kepedulian sosial perlu ditingkatkan dengan even-even kebersamaan untuk melatih empati, kepekaan sosial, solidaritas dan kebersamaan. Komunikasi antarwarga perlu terus dibangun di berbagai kesempatan dan tempat. Melalui komunikasi ini banyak hal yang tersampaikan sehingga para warga dapat saling memahami. Perbedaan-perbedaan yang ada justru bisa menjadi topik menarik dalam temu warga dan dapat mengakrabkan mereka.

\section{b. Membudayakan Komitmen Berbangsa dan Bernegara}

Melalui berbagai suasana dan cara ditanamkan komitmen menjaga esensi kemanusiaan dalam berbangsa dan negara di tengah realitas sebagai masyarakat yang multikultural dan beragam kepentingan. Maka warga masyarakat perlu disadarkan bahwa seseorang tidak mungkin dapat melangkah sendirian tanpa orang lain. Semua kelompok masyarakat mempunyai hak dan kewajiban yang sama di mata hukum. Komitmen berbangsa dan bernegara berarti komitmen untuk tidak melakukan penindasan, diskriminasi, serta aksi kekejaman, kejahatan, penganiayaan terhadap kelompok anak bangsa sendiri maupun bangsa lain. Menegakkan supremasi hukum dan mempercayakan penyelesaian permasalahan pada aparat penegak hukum merupakan komitmen bernegara dan berbangsa. Karena dengan begitu menghormati perangkat-perangkat negara yang diciptakan untuk keteraturan bernegara. Komitmen ini harus ditanamkan seawal mungkin, baik melalui lembaga keluarga, persekolahan maupun lembaga masyarakatsecara luas dan berkesinambungan. Program-programnya perlu perencanaan yang berkelanjutan, sebab ini berkaitan dengan nation building.

c. Melatih Warga Bangsa Mampu hidup dalam keberagaman

Hal ini sangat memungkinkan untuk dilakukan mulai dari keluarga, dalam kehidupan warga sekitar, di sekolah sampai dalam komunitas yang lebih luas. Para pendidik dapat menanamkan dan melatihkan pada siswa untuk mampu melakukan soft skill yang berkaitan dengan substansi nilai-nilai multikultural, seperti mampu menerima perbedaan, toleransi, menghormati pendapat orang lain, bekerja sama, mampu menganalisis persamaan dan perbedaan yang ada pada orang lain, mampu berlaku adil, mampu melihat ketimpangan sosial, dan mencari solusinya (problem solving). Selain itu membiasakan warga untuk saling membantu tanpa memandang perbedaan agama, status sosial, gender, umur, wilayah tempat tinggal (desa/kota). Dengan demikian sejak awal anggota masyarakat dilatih untuk mampu menyesuaikan diri dan hidup dalam keragaman serta mampu berperilaku sesuai dengan karakter bangsa Indonesia yang multikultural. Untuk dapat melaksanakannya diperlukan kebijakan dari penyelenggaran negara, organisasi masyarakat, organisasi keagamaan, partai dan lembaga-lembaga masyarakat lainnya. Kebijakan itu kemudian diwujudkan ke dalam program praktik 
terencana dan disesuaikan dengan kondisi maupun potensi masyarakatnya.

d. Melatihkan Kemampuan untuk Memahami Ideologi (Agama) Lain

Warga bangsa Indonesia merupakan masyarakat religius yang berlandaskan pada ajaran agama yang diakui di Indonesia (Islam, Kristen, Katolik, Hindu, Budha) dan aliran kepercayaan. Ini perwujudan dari sila pertama, yaitu Ketuhanan Yang Maha Esa. Dengan demikian, pada setiap warga negara perlu ditanamkan kesadaran bahwa di Indonesia terdapat bermacam-macam ideologi dan agama. Setiap manusia mempunyai agama ataupun ideologi yang tidak harus sama dengan ideologi kita. Oleh sebab itu yang paling baik adalah memahami substansi ideologi dan agama tersebut sebagai sebuah ajaran yang mencita-citakan kedamaian dan kebaikan. Bila hal ini dilaksanakan dengan sungguh-sungguh maka konflik antaragama tidak akan terjadi.

\section{e. Mengembangkan dan Melestarikan tradisi}

Pengakuan terhadap bangsa Indonesia yang terdiri dari beratus suku bangsa, berarti mengakui keragaman budaya dan tradisi yang hidup serta berkembang di Indonesia. Setiap warga bangsa harus mengetahui dan memahami negara Indonesia kaya akan tradisi bangsa. Menghormati budaya sendiri dan melestarikannya merupakan upaya menanamkan sikap kebangsaan yang kuat pada diri sendiri. Sehingga tercipta suatu identitas/ komunitas yang dapat melahirkan karakter sebuah bangsa. Pemahaman keberagaman yang multikultural berarti menerima adanya keragaman ekspresi budaya yang mengandung nilai-nilai kemanusiaan dan keindahan. Keragaman budaya dan tradisi yang ada dari sub nasional atau etnis, merupakan kekayaan bangsa dan negara. Negara harus menjamin kebebasan pengembangan dan pelestarian tradisi dan budaya daerah (lokal) atau etnis. Pengembangan dan pelestarian tradisi dan budaya daerah (etnis) ini, bukan untuk menguatkan primordialisme kesukuan, tetapi untuk menguatkan kekayaan khasanah budaya nasional yang pada dasarnya berasal dari budaya sub-nasional.

\section{f. Mewajibkan Media Massa Mengambil Peran dalam Membangun Karakter Bangsa \\ Media massa, khususnya mempengaruhi} pembentukan watak dan akhlak bangsa, diharapkan dapat mengambil peran sosiokultural, sosial-ekonomi, sosial-politik untuk tugas nation and character building (membangun karakter bangsa), dan pengukuran kebhinneka-tunggalikaan. Dengan adanya dialog, persuasif, dan menyamakan pandangan untuk kepentingan bangsa dan negara, antara para pemimpin media massa dengan pemimpin-pemimpin negara dan masyarakat diperoleh kesepakatan, kebersamaan kewajiban dan kepedulian untuk bersama-sama membangun karakter bangsa di bidangnya masing-masing. Melalui media massa dapat dikembangkan tentang pentingnya bangsa memiliki karakter, serta dapat disosialisasikan strategi untuk membangunnya.

Dari strategi tersebut akan dihasilkan sejumlah nilai nilai pendidikan karakter untuk pendidikan budaya dan karakter bangsa (Upputra, 2016: http://guruppkn.com), yaitu:

1. Religius : Merupakan sikap yang memegang teguh perintah agamanya dan menjauhi larangan agamanya, seraya saling menjaga kerukunan dan kesatuan antar berbeda pemeluk agama dan keyakinan.

2. Jujur: Merupakan sikap yang selalu berpegang teguh untuk menghindari keburukan dengan menjaga perkataan, perasaan dan perbuatan untuk selalu berkata dengan benar dan dapat 
dipercaya.

3. Toleransi: Perilaku yang cenderung menghargai perbedaan dengan mengurangi mempertajam perselisihan karena perbedaan. Perilaku ini diwujudkan dengan penerimaan atas perbedaan, dan keragaman sebagai suatu kekayaan bangsa Indonesia untuk mewujudkan fungsi toleransi dalam kehidupan berbangsa dan bernegara.

4. Disiplin: Tindakan yang menjaga dan mematuhi anjuran yang baik dan menghindari dan menjauhi segala larangan yang buruk secara konsisten dan berkomitmen.

5. Kerja keras: Mencurahkan segala kemampuan dan kemauan untuk menyelesaikan suatu pekerjaan sesuai hasil yang diharapkan dengan tepat waktu dan berorientasi lebih pada proses dan perkembangan daripada berorientasi pada hasil.

6. Kreatif: Selalu mencari alternatif penyelesaian suatu permasalahan dari berbagai sudut pandang. Ini dilakukan untuk mengembangkan tata cara atau pemahaman terhadap suatu masalah yang sudah ada terlebih dahulu melalui pendekatan sudut pandang yang baru.

7. Mandiri: Meyakini potensi diri dan melakukan tanggung jawab yang diembannya dengan penuh percaya diri dan berkomitmen.

8. Demokratis: sikap dan tindakan yang menilai tinggi hak dan kewajiban dirinya dan orang lain dalam kedudukan yang sama. Ini dilakukan untuk memberikan pengakuan secara setara dalam hak berbangsa seraya merawat kemajemukan bangsa indonesia

9. Rasa ingin tahu: suatu sikap dan tindakan yang selalu berupaya untuk mengetahui apa yang dipelajarinya secara lebih mendalam dan meluas dalam berbagai aspek terkait.
10. Semangat kebangsaan: Suatu sudut pandang yang memandang dirinya sebagai bagian dari bangsa dan negaranya. Sudut pandang yang mewujudkan sikap dan perilaku yang akan mempertahankan bangsa dari berbagai ancaman, serta memahami berbagai faktor penyebab konflik sosial baik yang berasal dari luar maupun dari dalam.

11. Cinta tanah air: tekad yang terwujud dalam perasaan, perilaku dan perkataan yang menunjukkan kesetiaan, kepedulian, dan penghargaan yang tinggi terhadap aspek sosial, fisik budaya, ekonomi, dan politik dari bangsa dan negaranya.

12. Menghargai prestasi: perasaan bangga terhadap kelebihan dan keunggulan yang dimiliki dirinya sebagai individu maupun dirinya sebagai anggota masyarakat. Perasaan bangsa ini akan mendorong untuk memperoleh pencapaian-pencapaian yang positif bagi kemajuan bangsa dan negara.

13. Bersahabat/komunikatif: Perilaku yang ditunjukan dengan senantiasa menjaga hubungan baik dengan interaksi yang positif antar individu dalam suatu kelompok dalam kehidupan berbangsa dan bernegara.

14. Cinta damai: Perilaku yang selalu mengutamakan kesatuan rasa dan perwujudan harmoni dalam lingkungan yang majemuk dan multikultural.

15. Senang membaca: Rasa ingin meningkatkan pengetahuan dan pemahaman melalui gemar mencari informasi baru lewat bahan bacaan maupun mengajak masyarakat di lingkungan sekitarnya untuk memupuk perasaan gemar membaca ini.

16. Peduli sosial: Kepekaan akan segala kesulitan yang dihadapi oleh lingkungannya dan masyarakatnya. 
Kepekaan ini kemudian terwujud dalam tindakan, perasaan, dan perbuatan yang berulang-ulang dan menjadi kebiasaan dalam mengatasi berbagai kesulitan yang dihadapi oleh orang-orang di sekitarnya, yang mana individu tidak terfokus pada dirinya sendiri dan bekerja sama dalam mengatasi permasalahan yang dihadapi.

17. Peduli lingkungan: Menjadikan pelestarian alam sebagai salah satu dasar perilaku dan kebiasaan yang dicerminkan di lingkungannya agar terus terjadi siklus pembaharuan di alam yang berkesinambungan secara alami. Ini dilakukan agar alam yang ditempatinya tetap lestari dan abadi.

18. Tanggung Jawab : Menyadari bahwa segala hal yang diperbuat oleh dirinya bukan hanya merupakan tugas dan kewajiban bagi dirinya sendiri, namun juga keluarga, lingkungan, masyarakat, negara, dan Tuhan Yang Maha Esa

Berdasarkan uraian tersebut dapat digambarkan bahwa pembangunan karakter bangsa menjadi hal yang mendesak untuk kita segerakan. Melalui pendidikan, khususnya pendidikan kewarganegaraan atau ciiv education, pembangunan karakter bangsa itu dapat dimulai. Sasarannya tentu saja adalah pembangunan watak individu manusia Indonesia. Untuk hal ini, penguatan spiritualitas dan akhlaq menjadi salah satu prioritas penting. Sebab civic education bukan sekadar proses untuk membuat seseorang itu mengetahui apa hak-haknya sebagai warga negara, akan tetapi lebih dari itu dimaksudkan juga untuk mendidik setiap individu agar dapat bersikap secara proporsional karena dilandari oleh watak mandiri, watak manusia yang oleh Allah diciptakan sebagai makhluk yang merdeka. Baru dengan begitulah kita berhak untuk berharap bahwa bangsa besar ini akan mampu menegakkan kepalanya berhadapan dengan bangsa-bangsa lain di dunia. Baru dengan begitu pulalah bangsa besar ini tidak akan mudah diombang-ambingkan oleh pemaksaan hegemoni negara lain (Haryono, 2012).

\section{SIMPULAN}

Kemajemukan atau heterogenitas bangsa Indonesia yang langka dimiliki oleh negara lain tersebut, menjadi modal sosial dengan konstruksi budayanya yang berbasis kearifan lokal (local genius). Heterogenitas bangsa Indonesia sebagai bangsa yang beradab tentunya harus dijaga dan dilestarikan sebagai khasanah budaya nasional. Dalam konteks interaksi sosial baik secara horizontal maupun vertikal realita pluralitas tersebut, dibutuhkan instrumen pendidikan yang berkarakter terbuka, inklusif, toleran dan pluralis. Pada konteks ini terminologi pendidikan multikultural menjadi istilah yang relevan untuk dikembangkan dalam ranah pendidikan Indonesia sebagai bangsa yang plural.

Pendidikan multikultural adalah strategi pendidikan yang diaplikasikan pada semua jenis mata pelajaran dengan cara menggunakan perbedaan-perbedaan kultural yang ada pada para siswa seperti perbedaan etnis, agama, bahasa, gender, kelas sosial, ras, kemampuan dan umur agar proses belajar menjadi efektif dan mudah. Pada konteks ini Pendidikan Kewarganegaraan merupakan topik sentral sebagai wahana pengembangan dan desimenasi pendidikan multikultural dalam masyarakat yang pluralis seperti Indonesia.

\section{DAFTAR PUSTAKA}

Dewangga, Thanon Aria. 2012. Pendidikan Karakter Untuk Membangun Manusia Indonesia Yang Unggul. Dalam: http:// www.unidayan.ac.id. Diunduh: 20-082016.

Membangun Karakter Bangsa Melalui 
Hanum,Farida.2011.PendidikanMultikultural dalam Mambangun Karakter Bangsa. Dalam: http://uun-halimah.blogspot. co.id. Diunduh: 20-08-2016.

Haryono, Tri Joko Sri. 2012. Membangun Karakter Bangsa melalui Pendidikan. Dalam: http://trijokoantro-fisip.web. unair.ac.id. Diunduh: 20-08-2016.

Lickona, Thomas. 1992. Educating for Character. How our school can teach respect and responsibility. New York: Bantam Books.

Upputra, Putra. 2016. 18 Nilai-nilai Pendidikan Karakter. Dalam: http:/guruppkn.com. Diunduh: 20-08-2016. 